\title{
Chemical Constituents and Antimicrobial Activity of Essential Oil of Senna podocarpa (Guill. et Perr.) Lock
}

\author{
Muritala A. Adebayo1, Oladipupo A. Lawal'2, Adeshina A. Sikiru², Isiaka A. Ogunwande ${ }^{2 *}$, \\ Opeyemi N. Avoseh² \\ ${ }^{1}$ Department of Pharmacognosy, Igbinedion University, Okada, Nigeria \\ ${ }^{2}$ Natural Product Research Unit, Department of Chemistry, Faculty of Science, Lagos State University, \\ Ojo, Nigeria \\ Email: ${ }^{\text {isiaka.ogunwande@lasu.edu.ng }}$
}

Received 24 May 2014; revised 28 June 2014; accepted 19 July 2014

Copyright (C) 2014 by authors and Scientific Research Publishing Inc.

This work is licensed under the Creative Commons Attribution International License (CC BY). http://creativecommons.org/licenses/by/4.0/

(c) (7) Open Access

\section{Abstract}

The chemistry of essential obtained from the leaves of Senna podocarpa (Guill. Et Perr.) Lock from Nigeria is being reported. The hydrodistilled oil was analyzed by gas chromatography-flame ionization detector (GC-FID) and gas chromatography-mass spectrometry (GC-MS) techniques. The main constituents of the oil were 1,2-benzenedicarboxylic acid, mono (2-ethylhexyl) ester phthalate $(26.6 \%)$ and $\beta$-elemene $(27.9 \%)$. There were significant amounts of caryophyllene oxide (7.3\%) and urs-12-en-24-oic acid, 3-oxo-methyl ester (5.5\%). The antimicrobial activity of the essential oil was evaluated against a panel of seven bacteria and two fungal strain using agar diffusion and broth microdilution methods. Results had shown that the oil exhibited moderate to strong antimicrobial activity against the tested microorganisms. The activity zones of inhibition (ZI) ranged between $10.0 \pm 0.2 \mathrm{~mm}$ and $28.3 \pm 2.9 \mathrm{~mm}$ while the minimum inhibitory concentrations (MIC) ranged between $0.3 \mathrm{mg} / \mathrm{mL} 5.0 \mathrm{mg} / \mathrm{mL}$, respectively. The chemical constituents and antimicrobial activity of the essential oil of Senna podocarpa were being reported for the first time.

\section{Keywords}

Senna podocarpa, Essential Oil Composition, Mono (2-Ethylhexyl) Ester Phthalate, $\beta$-Elemene, Antimicrobial Activity

\footnotetext{
"Corresponding author.
}

How to cite this paper: Adebayo, M.A., Lawal, O.A., Sikiru, A.A., Ogunwande, I.A. and Avoseh, O.N. (2014) Chemical Constituents and Antimicrobial Activity of Essential Oil of Senna podocarpa (Guill. et Perr.) Lock. American Journal of Plant Sciences, 5, 2448-2453. http://dx.doi.org/10.4236/ajps.2014.515259 


\section{Introduction}

Senna podocarpa (Guill. et Perr.) Lock., is a glabrous shrub usually 1 - 2 m high. The leaves are alternate, stipulate and pari-pinnate with 3 - 5 pairs of leaflets in a $15-30 \mathrm{~cm}$ long rachis. The flowers are yellowish up to 3 $\mathrm{cm}$ diameter in dense terminal spikes $20-30 \mathrm{~cm}$ long. The seeds (about 12 - 25) are black which cause transversal waving in pod valves [1]. The leaves and fruits are strongly purgative. The decoction of the leaves, roots and flowers is given for the treatment of veneral diseases in women. Fresh leaves are applied as poultices for the treatment of wounds, swellings, skin diseases and yawns [1].

A report indicated that the aqueous infusion of S. podocarpa pod was devoid of overt acute and sub-chronic toxic effects in mice and rats [2] [3]. The hydromethanolic leaf extracts of S. podocarpa have potent antioxidant properties and cytotoxic to the K562 leukaemia cell line [4] and the extracts may be useful in the management/ improvement of anemic conditions [5]. Methanol extract of the plant was shown to displayed antimicrobial activity [6], antiviral activity [7], increased intestinal motility of rats [8]-[10] and possessed laxative property [11]. The phytochemical screening showed the presence of saponins, tannins, anthraquinone, phlobatanin, phenolics, flavonoids and alkaloids [4]-[6] [12]. In addition, compounds such as rhein, emodin, chrysophanol, rhein-anthroneglucoside, sennoside A and sennoside B have been characterized from the plant [13].

Till present, there is no report on the chemical constituents of its essential while only one report indicates that the leaf essential oil possesses moderate antimicrobial activity [14]. In this paper, we report the compounds identified in the leaf essential oil of S. podocarpa as well as its antimicrobial potentials. This research is part of continued interest on the chemical analysis of poorly studied species of Nigeria flora [15].

\section{Materials and Methods}

\subsection{Plant Sample}

Fresh leaves of S. podocarpa were collected in March 2013, from a location in Ore, Ondo State, Nigeria. The sample was taxonomically identified by Curators at the Herbarium of the Forestry Research Institute of Nigeria (FRIN), Ibadan, Nigeria, where voucher specimen FHI 109,903 was deposited for future reference.

\subsection{Extraction of Essential Oil}

The air-dried plant sample (600 g) was pulverised and hydrodistilled for $4 \mathrm{~h}$ using a modified Clevenger-type apparatus according to the British Pharmacopoeia specification [16] to yield colourless essential oil. The distilled oil was collected over water and stored under refrigeration until analysis.

\subsection{Analysis of the Oil}

GC analysis of the oil was carried out on a Hewlett Packard HP 6820 Gas Chromatograph equipped with a FID detector and DB-5 column ( $60 \mathrm{~m} \times 0.25 \mathrm{~mm}$ i.d., film thickness, $0.25 \mu \mathrm{m})$ at the split ratio of 1:25. The oven temperature was programmed from $50^{\circ} \mathrm{C}$ (after $2 \mathrm{~min}$ ) to $240^{\circ} \mathrm{C}$ at $5^{\circ} \mathrm{C} / \mathrm{min}$ and the final temperature was held for $10 \mathrm{~min}$. Injection and detector temperatures were maintained at $200^{\circ} \mathrm{C}$ and $240^{\circ} \mathrm{C}$, respectively. Hydrogen was the carrier gas at the flow rate $1 \mathrm{~mL} / \mathrm{min}$. An aliquot of $0.2 \mu \mathrm{L}$ of the diluted oil was injected into the GC. Peaks were measured by electronic integration. A homologous series of $n$-alkanes were run under the same conditions for determination of retention indices. The relative amounts of individual components were calculated based on the GC peak area (FID response) without using correction factors.

GC-MS was performed on a Hewlett Packard Gas Chromatography HP 6890 interfaced with a Hewlett Packard 5973 mass spectrometer system equipped with a DB-5 capillary column $(30 \mathrm{~m} \times 0.25 \mathrm{~mm}$ i.d., film thickness $0.25 \mu \mathrm{m}$ ). The oven temperature was programmed from $70^{\circ} \mathrm{C}-240^{\circ} \mathrm{C}$ at the rate of $5^{\circ} \mathrm{C} / \mathrm{min}$. The ion source was set at $240^{\circ} \mathrm{C}$ and electron ionization at $70 \mathrm{eV}$. Helium was used as the carrier gas at a flow rate of 1 $\mathrm{mL} / \mathrm{min}$. The scanning range was 35 to $425 \mathrm{amu}$.

\subsection{Identification of the Constituents}

The identification of constituents was performed on the basis of retention indices (RI) determined with reference to the homologous series of $n$-alkanes, under identical experimental conditions, co-injection with standards (Sigma-Aldrich, St. Louis, MO, USA) or known essential oil constituents, authentic collection of Mass spectra data of known compounds and by comparing with MS literature data [17] [18]. 


\subsection{Antimicrobial Assay}

\subsubsection{Microorganisms}

Nine local isolates comprising of two gram-positive bacteria, five gram-negative bacteria strains and two fungi obtained from the Department of Microbiology, Lagos State University, Ojo, Lagos and Nigerian Institute of Medical Research (NIMR), Yaba, Lagos, Nigeria, respectively were used for this study. These microorganisms were Bacillus subtilis, Staphylococcus aureus, Escherichia coli, Kiebsiella spp., Proteus spp., Pseudomonas spp., Salmonella spp., Penicillium notatum and Rhizopus stolonifer. The stock cultures were maintained at $4^{\circ} \mathrm{C}$ in Müeller-Hinton agar (Oxoid, Germany).

\subsubsection{Determination of Antimicrobial Activity}

The antibacterial activity of essential oil of $S$. podocarpa was measured by disc-diffusion method [19]. The microorganisms were grown overnight at $37^{\circ} \mathrm{C}$ in $10 \mathrm{~mL}$ of Mueller Hinton Broth (Oxoid Ltd, England) for $24 \mathrm{~h}$. The cultures were adjusted with sterile saline solution to obtain turbidity comparable to that of McFarland no. 0.5 standard $\left(1.0 \times 10^{8} \mathrm{CFU} / \mathrm{mL}\right)$. Petri dishes containing Müeller-Hinton agar (Oxoid Ltd, England) were inoculated with the microbial suspensions. Sterile Whatman No.1 $(6 \mathrm{~mm})$ discs paper was placed on the surface of the seeded agar plates and $10 \mu \mathrm{L}$ of $40 \mathrm{mg} / \mathrm{mL}$ of each extract in dimethylsulfoxide was applied to the filter paper disk. The plates were incubated overnight at $37^{\circ} \mathrm{C}$ for $24 \mathrm{~h}$ and the diameter of any resulting zones of inhibition (mm) was measured. Each experiment was carried out in triplicates. Standard antibiotic discs (gentamycin and nalidixic acid) and 1\% DMSO solution ((positive and negative controls) were also run in parallel along with the extracts.

\subsubsection{Determination of Minimum Inhibitory Concentration (MIC)}

A broth microdilution method was used to determine the MIC of S. podocarpa oil [20]. Bacterial cultures were incubated in Müeller-Hinton (MH) broth overnight at $37^{\circ} \mathrm{C}$ and a 1:1 dilution of each culture in fresh $\mathrm{MH}$ broth was prepared prior to use in the micro dilution assay. One hundred $\mu \mathrm{L}$ of bacterial culture of an approximate inoculum size of $1.0 \times 10^{8} \mathrm{CFU} / \mathrm{mL}$ was added to all well and incubated at $37^{\circ} \mathrm{C}$ for $24 \mathrm{H}$. After incubation, $40 \mu \mathrm{L}$ of $0.2 \mathrm{mg} / \mathrm{mL} p$-iodonitotetrazolium violet (INT) solution was added to each well and incubated at $37^{\circ} \mathrm{C}$. Plates were examined after about 30 min of incubation. Microbial growth is indicated by the presence of a reddish colour, which is produced when INT, a dehydrogenase activity-detecting reagent is reduced by metabolically active microorganisms to the corresponding intensely coloured formazan. MIC is defined as the lowest concentration that produces an almost complete inhibition of visible microorganism growth in liquid medium. Solvent control (DMSO solution) and standard antibiotics (gentamycin and nalidixic acid) were included in the assay.

\subsection{Statistical Analysis}

The mean and standard deviation of three experiments were determined for zones of inhibition. Statistical analysis of the differences between mean values obtained for experimental groups were calculated using Microsoft excel program, 2003 [21]. Data were subjected to one way analysis of variance (ANOVA). $P$ values $\leq 0.05$ were regarded as significant and $P$ values $\leq 0.01$ as very significant.

\section{Results and Discussion}

\subsection{Chemical Constituents}

The yield of the oil obtained from the hydrodistillation procedure was $1.13 \%(\mathrm{v} / \mathrm{w})$, calculated on a dry weight basis. Table 1 indicates the list of 19 compounds identified in the leaf oil of S. podocarpa. These amounted to 93.7\% of the total oil content. Monoterpene compounds were conspicuously absent in the oil. Sesquiterpene hydrocarbons (42.0\%), oxygenated sesquiterpenes (8.7\%), phthalate (26.6\%), triterpenes (10.5), diterpenes (2.8\%) and alkanes (2.1\%) were the main classes of compounds identified in the oil. The major compounds were identified as 1,2-benzenedicarboxylic acid, mono (2-ethylhexyl) ester phthalate (26.6\%) and $\beta$-elemene (27.9\%). There were significant amounts of caryophyllene oxide (7.3\%), urs-12-en-24-oic acid, 3-oxo-methyl ester (5.5\%), $\beta$-caryophyllene (3.1\%), $\gamma$-muurolene (3.0\%) and (3 $\beta$ )-lup-20(29)-en-3-ol, acetate (3.0\%).

Although literature citation on the composition of the essential oil of $S$. podocarpa is scarce, the oil contents of some Senna species have been documented. The major components of the oil of Senna alata were ar-tur- 
Table 1. Essential oil constituents of Senna podocarpa.

\begin{tabular}{|c|c|c|c|}
\hline Compounds $^{\mathrm{a}}$ & $\mathbf{R I}^{\mathbf{b}}$ & $\mathbf{R I}^{\mathbf{c}}$ & Percentage (\%) \\
\hline$\alpha$-copaene & 1371 & 1372 & 1.0 \\
\hline (E)-4-tetradecene & 1380 & 1379 & 2.1 \\
\hline$\beta$-elemene & 1389 & 1393 & 17.9 \\
\hline$\beta$-caryophyllene & 1426 & 1417 & 3.1 \\
\hline$\alpha$-humulene & 1454 & 1452 & 0.9 \\
\hline$\gamma$-muurolene & 1479 & 1477 & 3.0 \\
\hline$\gamma$-elemene & 1489 & 1482 & 0.7 \\
\hline$\beta$-selinene & 1491 & 1489 & 2.0 \\
\hline$\alpha$-selinene & 1495 & 1494 & 1.3 \\
\hline$\delta$-cadinene & 1527 & 1522 & 1.4 \\
\hline$\alpha$-calacorene & 1541 & 1543 & 0.7 \\
\hline (E)-nerolidol & 1564 & 1561 & 0.5 \\
\hline Caryophyllene oxide & 1588 & 1583 & 7.3 \\
\hline Humulene epoxide II & 1603 & 1606 & 0.9 \\
\hline Phytol & 2118 & 1942 & 2.8 \\
\hline 1,2-benzenedicarboxylic acid, mono (2-ethylhexyl) ester & 2549 & 2553 & 26.6 \\
\hline Urs-12-en-24-oic acid, 3-oxo-, methyl ester & 2720 & 2710 & 5.5 \\
\hline Lanosta-8,24-dien-3-ol, acetate, $(3 \beta)$ & 3331 & 3339 & 2.0 \\
\hline Lup-20(29)-en-3-ol, acetate, (3 $\beta)$ & 3381 & 3372 & 3.0 \\
\hline Total & & & 93.7 \\
\hline
\end{tabular}

${ }^{\mathrm{a}}$ Elution order on DB-5 column. ${ }^{\mathrm{b}}$ Retention indices on DB-5 column. ${ }^{\mathrm{c}}$ Literature retention indices.

merone (13.5\%), $\beta$-caryophyllene (7.3\%), (E)-phytol (7.0\%) and 6,10,14-trimethyl-2-pentadecanone (6.8\%). while the quantitatively significant constituents in Senna occidentalis leaf oil were $(E)$-phytol (26.0\%), hexadecanoic acid (17.3\%) and 6,10,14-trimethyl-2-pentadecanone (9.9\%). (E)-phytol (30.8\%), pentadecanal (21.7\%) and 6,10,14-trimethyl-2-pentadecanone (3.8\%) were identified as principal components of Senna hirsuta from Nigeria [22]. The quantitatively significant constituents of the leaf oil of Cassia alata from Nigeria [23] were 1, 8-cineole (39.8\%), $\beta$-caryophyllene (19.1\%) and caryophyllene oxide (12.7\%). The essential oil obtained by hydrodistillation of leaves of $C$. alata collected in Gabon [24] was found to contained linalool (23.0\%), borneol $(8.6 \%)$ and pentadecanal (9.3\%) as the major constituents. The analysis of chemical compositions of essential oils of Cassia fistula growing in Egypt [25] showed the main components of the flower were (E)-nerolidol (38.0\%), 2-hexadecanone (17.0\%) and heptacosane (12.8\%), while leaf was characterized by the abundance of phytol (16.1\%) together with the hydrocarbons, tetradecane (10.5\%) and hexadecane (8.7\%).

It could be seen that each oil sample has its own compositional pattern different from others. A noteworthy observation is the fact that mono (2-ethylhexyl) ester phthalate and $\beta$-elemene were not previously described as major constituents of any Senna oil. Mono (2-ethylhexyl) ester phthalate was the main constituents of essential oil of Polygonum chinense [26] and Iris germanica [27] where it was shown to exhibit good antimicrobial activities. The triterpene compounds of the oil of S. podocarpa have been found in other oil samples. 3 $\beta$-lup-20(29)en-3-ol-acetate is an important constituent of the volatile oil of Ficus auriculata [28] while lanosta-8,24-dien$3 \beta$-ol-acetate could be seen prominent in the oil of propolis [29].

\subsection{Antimicrobial Activity}

The results of antimicrobial study (Table 2) showed that $S$. podocarpa exhibited broad spectrum of antimicrobial activity against some of the tested microorganisms with IZ and MIC highest in $R$. stolonifer $(28.3 \pm 2.9 \mathrm{~mm}$ and $0.3 \mathrm{mg} / \mathrm{mL})$, E. coli $(15.3 \pm 0.5 \mathrm{~mm}$ and $0.6 \mathrm{mg} / \mathrm{mL})$ and $P$. notatum $(21.0 \pm 1.5 \mathrm{~mm}$ and $0.6 \mathrm{mg} / \mathrm{mL})$. However, moderate activity could be observed against $B$. subtilis $(12.0 \pm 1.0 \mathrm{~mm}$ and $1.3 \mathrm{mg} / \mathrm{mL})$, S. aureus (11.7 $\pm 1.2 \mathrm{~mm}$ and $1.3 \mathrm{mg} / \mathrm{mL})$, Pseudomonas spp. (17.0 $\pm 0.5 \mathrm{~mm}$ and $1.3 \mathrm{mg} / \mathrm{mL})$, Kiebsiella spp. (13.0 \pm 0.7 $\mathrm{mm}$ and $2.5 \mathrm{mg} / \mathrm{mL}$ ) and Proteus spp. (12.3 $\pm 1.3 \mathrm{~mm}$ and $2.5 \mathrm{mg} / \mathrm{mL})$. The leaf oil of S. podocarpa displayed poor activity against Salmonella spp. with IZ of $10.0 \pm 0.2 \mathrm{~mm}$ and MIC of $5 \mathrm{mg} / \mathrm{mL}$. 
Table 2. Antimicrobial activity of the essential oil of Senna podocarpa.

\begin{tabular}{ccccccc}
\hline \multirow{2}{*}{ Microorganisms } & \multicolumn{2}{c}{ S. podocarpa } & \multicolumn{2}{c}{ Gentamycin $^{\mathbf{d}}$} & \multicolumn{2}{c}{${\text { Nalidixic } \text { acid }^{\mathbf{d}}}^{\text {IZ }}$} \\
\cline { 2 - 6 } & IZ $^{\mathbf{b}}$ & MIC & IZ & MIC & IZ & MIC \\
\hline B. subtilis & $12.0 \pm 1.0$ & 1.3 & $20.7 \pm 1.2$ & 0.3 & $23.7 \pm 1.6$ & 0.3 \\
S. aureus & $11.7 \pm 1.2$ & 1.3 & $28.3 \pm 2.1$ & 0.6 & $24.3 \pm 1.5$ & 1.3 \\
E. coli & $15.3 \pm 0.5$ & 0.6 & $24.7 \pm 1.2$ & 0.3 & $15.7 \pm 1.2$ & 1.3 \\
Kiebsiella spp. & $13.0 \pm 0.7$ & 2.5 & $10.7 \pm 1.5$ & 2.5 & $23.7 \pm 1.6$ & 0.3 \\
Proteus spp. & $12.3 \pm 1.3$ & 2.5 & $12.3 \pm 2.5$ & 1.3 & $20.3 \pm 0.6$ & 0.6 \\
Pseudomonas spp. & $17.0 \pm 0.5$ & 1.3 & $15.7 \pm 2.1$ & 2.5 & $15.7 \pm 1.2$ & 1.3 \\
Salmonella spp. & $10.0 \pm 0.2$ & 5 & $22.0 \pm 2.0$ & 0.6 & $13.7 \pm 2.1$ & 2.5 \\
P. notatum & $21.0 \pm 1.5$ & 0.6 & $14.3 \pm 1.3$ & 1.3 & $15.7 \pm 1.2$ & 1.3 \\
R. stolonifer & $28.3 \pm 2.9$ & 0.3 & $20.7 \pm 1.2$ & 0.3 & $13.7 \pm 2.1$ & 2.5 \\
\hline
\end{tabular}

a $(\mathrm{n}=3, \mathrm{X} \pm \mathrm{SEM}) .{ }^{\mathrm{b}} \mathrm{IZ}$ : Inhibition zones diameter $(\mathrm{mm})$ including diameter of sterile disc $(6 \mathrm{~mm})$, with values given as mean \pm SD (3 replicates). ${ }^{\mathrm{c}}$ MIC values are given as $(\mathrm{mg} / \mathrm{ml}) .{ }^{\mathrm{d}}$ Methanolic solutions of Gentamycin and Nalidixic acid, $5 \mathrm{mg} / \mathrm{mL}$.

The oil acted more strongly against $R$. stolonifer, E. coli and P. notatum with MIC of $0.3,0.6$ and $0.6 \mathrm{mg} / \mathrm{mL}$ respectively. The antimicrobial activity of essential oil is related in most cases to its major components and the synergistic effects of the minor constituents should also be taken into consideration [23]. Referring to literature, mono (2-ethylhexyl) ester phthalate has shown considerable antimicrobial activities [26] [27]. In addition, essential oils with considerable amount of $\beta$-elmene have displayed potentials antimicrobial properties [30]. The present antimicrobial effects justify the use of $S$. podocarpa plant for treatment of various ailments. Therefore, it is recommended as a plant of phytopharmaceutical importance.

\section{Acknowledgements}

Authors are grateful to Mrs. Ogunwande Muslimat for the type setting of the manuscript. The effort of Mr. Daniel Mojiji of the University of Lagos, Nigeria, in the GC and GC/MS analysis was highly appreciated.

\section{References}

[1] Mabberly, D.J. (1987) The Plant-Book. A Portable Dictionary of Higher Plants. Cambridge University Press, Cambridge.

[2] Adefemi, O.A., Elujoba, A.A. and Odesanmi, W.O. (1988) Evaluation of the Toxicity Potential of Cassia podocarpa with Reference to Official Senna. West African Journal of Pharmacology and Drug Research, 8, 41-48.

[3] Akanmu, M.A., Iwalewa, E.O., Elujoba, A.A. and Adelusola, K.A. (2005) Toxicity Potentials of Senna podocarpa (Guill. et Perr.) Lock Pods in Rodents. African Journal of Traditional Complimentary and Alternative Medicine, 2, 274-281.

[4] Adebesin, O.A., Okpuzor, J., Iroanya, O.O., Adenekan, S.O. and Aniekwena, C. (2013) Antioxidant and Cytotoxic Properties of Senna alata and Senna podocarpa Leaf Extracts. Planta Medica, 79, 27. http://dx.doi.org/10.1055/s-0033-1351931

[5] Adebesin, O.A., Okpuzor, J. and Iroanya, O.O. (2013) Haematological, Biochemical and Antioxidant Properties of Hydromethanolic Extract of Senna alata and Senna podocarpa Leaves on Albino Rats. International Journal of Pharmaceutical and Chemical Sciences, 2, 876-880.

[6] Ogundare, O.A. (2009) The Antimicrobial Pattern and Phytochemical Properties of the Leaf Extracts of Senna podocarpa. African Journal of Microbiology Research, 3, 400-406.

[7] Silva, O., Barbosa, S., Diniz, A., Valdeira, M.L. and Gomes, E. (1997) Plant Extracts with Antiviral Activity against Herpes Simplex Virus Type 1 and African Swine Fever Virus. Pharmaceutical Biology, 35, 12-16. http://dx.doi.org/10.1076/phbi.35.1.12.13264

[8] Larbi, S.O. and Lewis, R.A. (1976) Biological Assay of Cassia podocarpa: A Plant Related to Senna. West African Journal Pharmacology and Drug Research, 3, 149-152. 
[9] Akomolafe, R.O., Adeoshun, I.O., Elujoba, A.A., Ayoka, A.O. and Iwalewa, E.O. (2004) An In-Vitro Study of the Effect of Cassia podocarpa Fruits on the Intestinal Motility of Rats. Phytomedicine, 11, 249-254. http://dx.doi.org/10.1078/0944-7113-00330

[10] Akomolafe, R.O., Adeoshun, I.O., Elujoba, A.A., Iwalewa, E.O. and Ayoka, A.O. (2004) Effects of Cassia podocarpa Leaves Extracts on Rat Ileum and Colon, (In-Vitro). Bulletins of Latin American and Carrebean Medicinal and Aromatic Plants, 3, 52-57.

[11] Elujoba, A.A., Ajulo, O.O. and Iweibo, G.O. (1989) Chemical and Biological Analyses of Nigerian Cassia Species for Laxative Activity. Journal of Pharmaceutical and Biomedical Analysis, 7, 1453-1457. http://dx.doi.org/10.1016/0731-7085(89)80150-5

[12] Ogunkunle, A.T.J. and Tonia, A.L. (2006) Ethnobotanical and Phytochemical Studies on Some Species of Senna in Nigeria. African Journal of Biotechnology, 5, 2020-2023.

[13] Dave, H. and Ledwani, L. (2012) A Review of Anthraquinones Isolated from Cassis Species and Their Applications. Indian Journal of Natural Products and Resources, 3, 291-319.

[14] Ajayi, I.A., Jonathan, S.G., Adewuyi, A. and Oderinde, R.A. (2008) Antimicrobial Screening of the Essential Oil of Some Herbal Plants from Western Nigeria. World Applied Sciences Journal, 3, 79-81.

[15] Lawal, O.A., Ogunwande, I.A., Bullem, C.A., Taiwo, O.T. and Opoku, A.R. (2014) Essential Oil Composition and in Vitro Biological Activities of Three Szyzgium Species from Nigeria. In: Jinnan, H., Ed., New Developments in Terpene Research, Nova Science Publisher Inc., New York, 93-112.

[16] (1980) British Pharmacopoeia. Vol. II, H.M. Stationary Office.

[17] Adams, R.P. (2007) Identification of Essential Oil Components by Gas Chromatography/Quadrupole Mass Spectrometry. 4th Edition, Allured Publishing Corporation, Carol Stream.

[18] Joulain, D. and Koenig, W.A. (1989) The Atlas of Spectral Data of Sesquiterpene Hydrocarbons. E.B. Verlag, Hamburg.

[19] Viljoen, A.M., van Vuuren, S.F., Gwebu, T., Demirci, B. and Baser, K.H.C. (2006) The Geographical Variation and Antimicrobial Activity of African Wormwood (Artemisia afra Jacq.) Essential Oil. Journal of Essential Oil Research, 18, $19-25$.

[20] Eloff, J.N. (1998) A Sensitive and Quick Microplate Method to Determine the Minimal Inhibitory Concentration of Plant Extracts for Bacteria. Planta Medica, 64, 711-713. http://dx.doi.org/10.1055/s-2006-957563

[21] Microsoft Excel (2003) Excel.

[22] Essien, E.E., Walker, T.M., Ogunwande, I.A., Bansal, A., Setzer, W.N. and Ekundayo, O. (2011) Volatile Constituents, Antimicrobial and Cytotoxicity Potentials of Three Senna Species from Nigeria. Journal of Essential Oil-Bearing Plants, 14, 722-730. http://dx.doi.org/10.1080/0972060X.2011.10643995

[23] Ogunwande, I.A., Flamini, G., Cioni, P.L., Omikorede, O., Azeez, R.A., Ayodele, A.A. and Yusuff, K.O. (2010) Aromatic Plants Growing in Nigeria: Essential Oil Constituents of Cassia alata (Linn.) Roxb. and Helianthus annuus L. Records of Natural Products, 4, 211-217.

[24] Agnaniet, H., Bikanga, R., Bessière, J.M. and Menut, C. (2005) Aromatic Plants of Tropical Central Africa. Part XLVI. Essential Oil Constituents of Cassia alata (L.) from Gabon. Journal of Essential Oil Research, 17, 410-412. http://dx.doi.org/10.1080/10412905.2005.9698946

[25] Tzakou, O., Loukis, A. and Said, A. (2007) Essential Oil from the Flowers and Leaves of Cassia fistula L. Journal of Essential Oil Research, 19, 360-361. http://dx.doi.org/10.1080/10412905.2007.9699305

[26] Bagavathi, P.E. and Ramasamy, N. (2012) GC-MS Analysis of Phytocompounds in the Ethanol Extracts of Polygonum chinense L. Pharmacognosy Research, 14, 11-14.

[27] Syeda, F.A., Habib-ur-Rahman, Choudahry, M.I. and Atta-ur-Rahman (2011) Gas Chromatography-Mass Spectrometry (GC-MS) Analysis of Petroleum Ether Extract (Oil) and Bioassays of Crude Extract of Iris germanica. International Journal of Genetics and Molecular Biology, 3, 95-100.

[28] Shao, T.-M., Song, X.-P., Chen, G.-Y., Li, X.-B., Yao, G.-G., Deng, K.-Y. and Huang, K.-L. (2013) Analysis of the Chemical Constituents of Volatile Oil from the Leaves of Ficus auriculata Lour by GC-MS. Chemistry and Industry of Forest Products, 33, 135-137.

[29] Zhao, Q., Zhang, B., Zhou, W. and Guo, Z.-F. (2007) Study of Essential Oils of Propolis by Microwave Assisted Extraction Coupled with GC-MS. Fine Chemicals, 12, 204-206.

[30] Elhawary, S.S., El Tantawy, M.E., Rabeh, M.A. and Fawaz, N.E. (2013) DNA Fingerprinting, Chemical Composition, Antitumor and Antimicrobial Activities of the Essential Oils and Extractives of Four Annona Species from Egypt. Journal of Natural Sciences Research, 3, 59-68. 
Scientific Research Publishing (SCIRP) is one of the largest Open Access journal publishers. It is currently publishing more than 200 open access, online, peer-reviewed journals covering a wide range of academic disciplines. SCIRP serves the worldwide academic communities and contributes to the progress and application of science with its publication.

Other selected journals from SCIRP are listed as below. Submit your manuscript to us via either submit@scirp.org or Online Submission Portal.
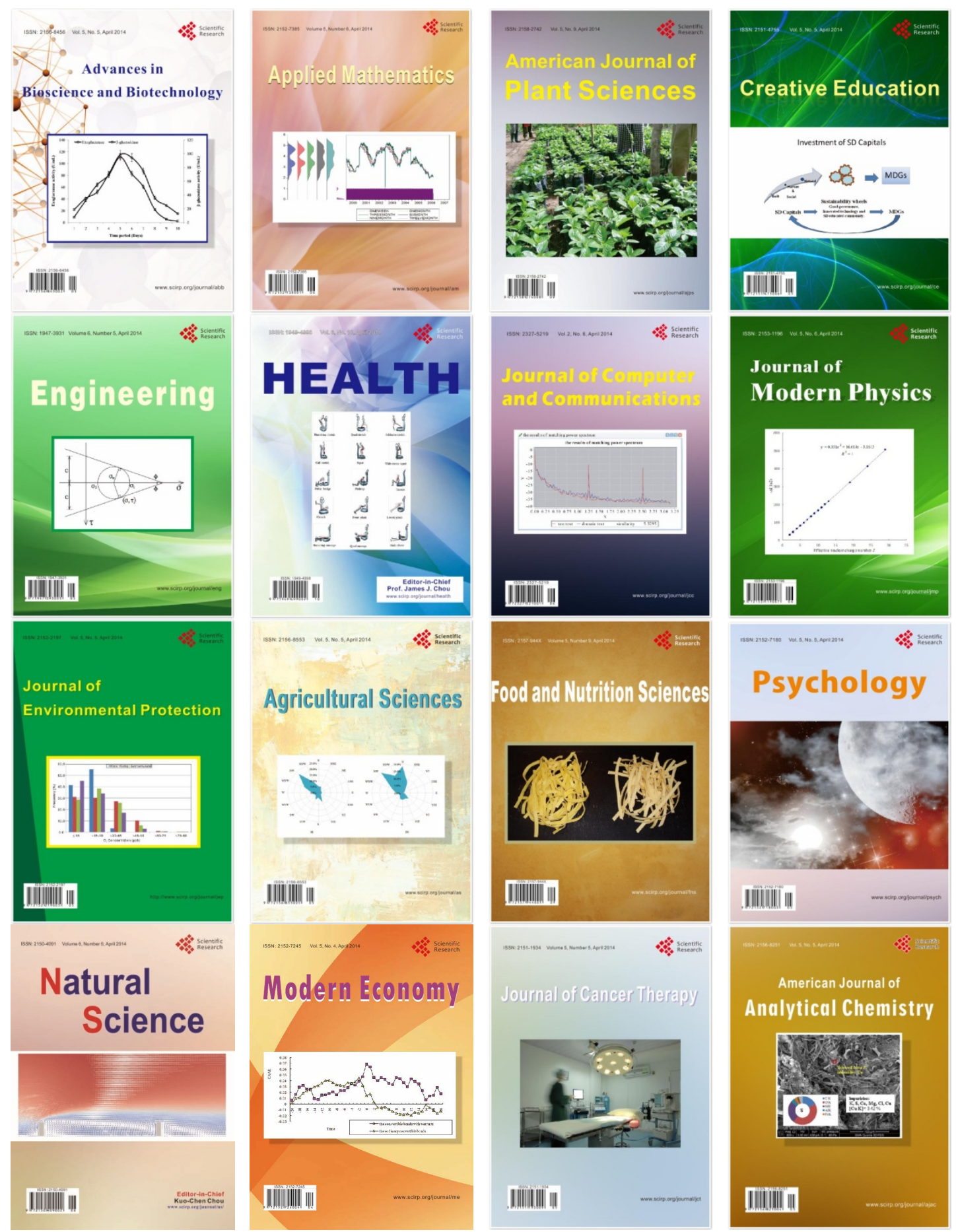